\title{
Identified Settlement Receptor Cells in a Nudibranch Veliger Respond to Specific Cue
}

\author{
STUART A. ARKETT ${ }^{1, *}$, FU-SHIANG CHIA ${ }^{2}$, JEFF I. GOLDBERG ${ }^{2}$, AND RON KOSS ${ }^{2}$ \\ ${ }^{1}$ Department of Biology, University of Victoria, Victoria, British Columbia, Canada V8W 2Y2, and \\ ${ }^{2}$ Department of Zoology, University of Alberta, Edmonton, Alberta, Canada T6G 2 E9
}

\begin{abstract}
Intracellular electrode recordings from sensory cells on the propodium of metamorphically competent veligers of the nudibranch Onchidoris bilamellata show a distinct response to a known settlement cue. Sensory cells responded to seawater conditioned with live barnacles with a slow (up to $60 \mathrm{~s}$ ), small amplitude (3$15 \mathrm{mV}$ ) depolarization. Lucifer Yellow injections of these cells reveal a single, flask-shaped cell, with dendritic processes extending to the surface of the propodium. We propose that these cells are primary receptor cells that are responsible for the detection of the specific settlement cue for Onchidoris veligers.
\end{abstract}

\section{Introduction}

Larvae of many marine benthic invertebrates utilize a variety of environmental cues to indicate settlement and metamorphosis sites (see reviews by Crisp, 1974; Scheltema, 1974; Chia and Rice, 1978; Burke, 1983). In molluscs, one cue that often induces settlement and metamorphosis is the principal prey of the adult (Thompson, 1958, 1962; Bonar and Hadfield, 1974; Perron and Turner, 1977; Chia and Koss, 1978; Bickell et al., 1981), and the nervous system is suspected in perceiving the settlement and metamorphosis cue (Baloun and Morse, 1984; Yool et al., 1986). Receptor organs and cells that presumably detect these settlement/metamorphosis cues have been described in some molluscan larvae at both the light and electron microscopy levels (Bonar, 1978; Chia and Koss, 1982, 1984). However, it has never been demonstrated that these complex receptor organs actually respond to a specific cue. We are totally ignorant of

Received 15 November 1988; accepted 30 January 1989.

* Present address: Department of Physiology, The Medical School, University Walk, Bristol, England BS8 1TD. the electrophysiological properties of these receptors and how they might transduce sensory information and trigger the complex behavior of settlement or the morphological changes of metamorphosis.

Todd (1979) and Chia and Koss (1988a) have shown that the nudibranch Onchidoris bilamellata exhibits complex settlement behavior in response to a specific cue. When metamorphically competent Onchidoris veligers are exposed to seawater that has been conditioned with live barnacles, they cease swimming and sink to the bottom. Upon contact with the bottom, the larval foot expands and begins rhythmical contortions. Veligers then crawl for up to $30 \mathrm{~min}$ and, if they do not encounter barnacles, begin swimming again. Chia and Koss (1988b) have described the morphology of receptor cells, associated with a unique ganglion, that may detect the Onchidoris settlement cue. The location of these cells can be readily identified under a dissecting microscope by an ovoid ciliation pattern on the sides of the propodium. Onchidoris thus presents a unique opportunity to characterize the electrophysiological properties of settlement receptor cells in response to a specific cue.

We have identified sensory cells in metamorphically competent Onchidoris veligers that respond to a known settlement cue. Intracellular electrode recordings from sensory cells on the propodium show small amplitude, slow depolarizations after the addition of seawater conditioned with live barnacles. Lucifer Yellow injections into these receptor cells reveal a single, flask-shaped cell located within a unique ganglion. This study represents the first demonstration of some of the electrophysiological properties of larval settlement receptor cells.

\section{Materials and Methods}

Egg ribbons from Onchidoris bilamellata (Linnaeus, 1767) were collected from Bamfield, Canada. Veliger lar- 
vae were raised according to Chia and Koss (1988a). The veligers used in these experiments were from the same cohort and random samples from the cohort were checked for metamorphic competency according to Chia and Koss (1988a). Only when the cohort reached competency did we attempt to record from a receptor cell.

Veligers were pipetted into a Sylgard (Dow Corning)lined recording dish containing $2.5 \mathrm{ml}$ of high $\mathrm{Mg}^{++}$, low $\mathrm{Ca}^{++}$seawater mixture $\left(12-15^{\circ} \mathrm{C}\right)$ consisting of natural seawater, isotonic $(0.33 \mathrm{M}) \mathrm{MgCl}_{2}$, and $\mathrm{Co}^{++}$-seawater in a ratio of $2: 1: 4.5(\mathrm{v} / \mathrm{v} / \mathrm{v})$. $\mathrm{Co}^{++}$-seawater consisted of $430 \mathrm{~m} M \mathrm{NaCl}, 10 \mathrm{~m} M \mathrm{CoCl}_{2}, 10 \mathrm{~m} M \mathrm{KCl}, 30 \mathrm{~m} M$ $\mathrm{MgCl}_{2}, 20 \mathrm{mM} \mathrm{MgSO}_{4}, 10 \mathrm{~m} M$ TES pH 7.8 (Arkett et al., 1987). We derived this bath mixture empirically and found that it abolishes most movements of the foot. Veligers were held in place by pinning the base of the velum with a cactus spine. A second spine was used to orient the veliger such that one side of the propodium and receptor field faced upward.

Conventional intracellular electrode recording techniques were used. Three $\mathrm{M} \mathrm{KCl}$ (20-40 MO) and Lucifer Yellow CH (Sigma, tip-filled with 5\% LY and back-filled with $1 \mathrm{M} \mathrm{LiCl}_{2} ; 80-100 \mathrm{MO}$ ) electrodes were routinely used. Lucifer Yellow was iontophoresed into receptor cells by passing brief ( $1-3 \mathrm{~s}$ duration, up to $5 \mathrm{nA}$ ) hyperpolarizing current pulses for about 3-5 min. Veligers were either viewed live, or fixed in $4 \%$ paraformaldehyde in $0.2 \mathrm{M}$ sodium phosphate buffer $\mathrm{pH} 7.4$ for $1 \mathrm{~h}$ at room temperature. After washing briefly in the same buffer, veligers were dehydrated in a graded series of ethanol, cleared in methyl salicylate and either viewed whole or embedded in Spurr's for sectioning. Whole mounts and $2 \mu \mathrm{m}$ sections were viewed with a Zeiss Photomicroscope II equipped with BP 450-490, FT 510 and BP 520-560 filters for Lucifer Yellow visualization.

The stimulus used to evoke settlement behavior was the same as that used by Chia and Koss (1988a) in that 25 living barnacles were soaked in filtered seawater for $24 \mathrm{~h}$. One hundred $\mu \mathrm{l}$ aliquots of seawater, conditioned with the barnacle Chthamalus dalli (Pilsbry, 1916), were pipetted toward the veliger after the resting potential stabilized. Most veligers were tested for their response only once. Control experiments used the same aliquot volume of culture water or bath seawater.

For scanning electron microscopy, larvae were relaxed in the $\mathrm{Co}^{++}$-seawater mixture described above, and processed according to the technique of McEuen (1985). Specimens were then examined with a Cambridge Stereoscan 250 SEM.

\section{Results}

While the veligers are pinned in the high $\mathrm{Mg}^{++}$, low $\mathrm{Ca}^{++}$seawater, pre-oral cilia beat continuously and the
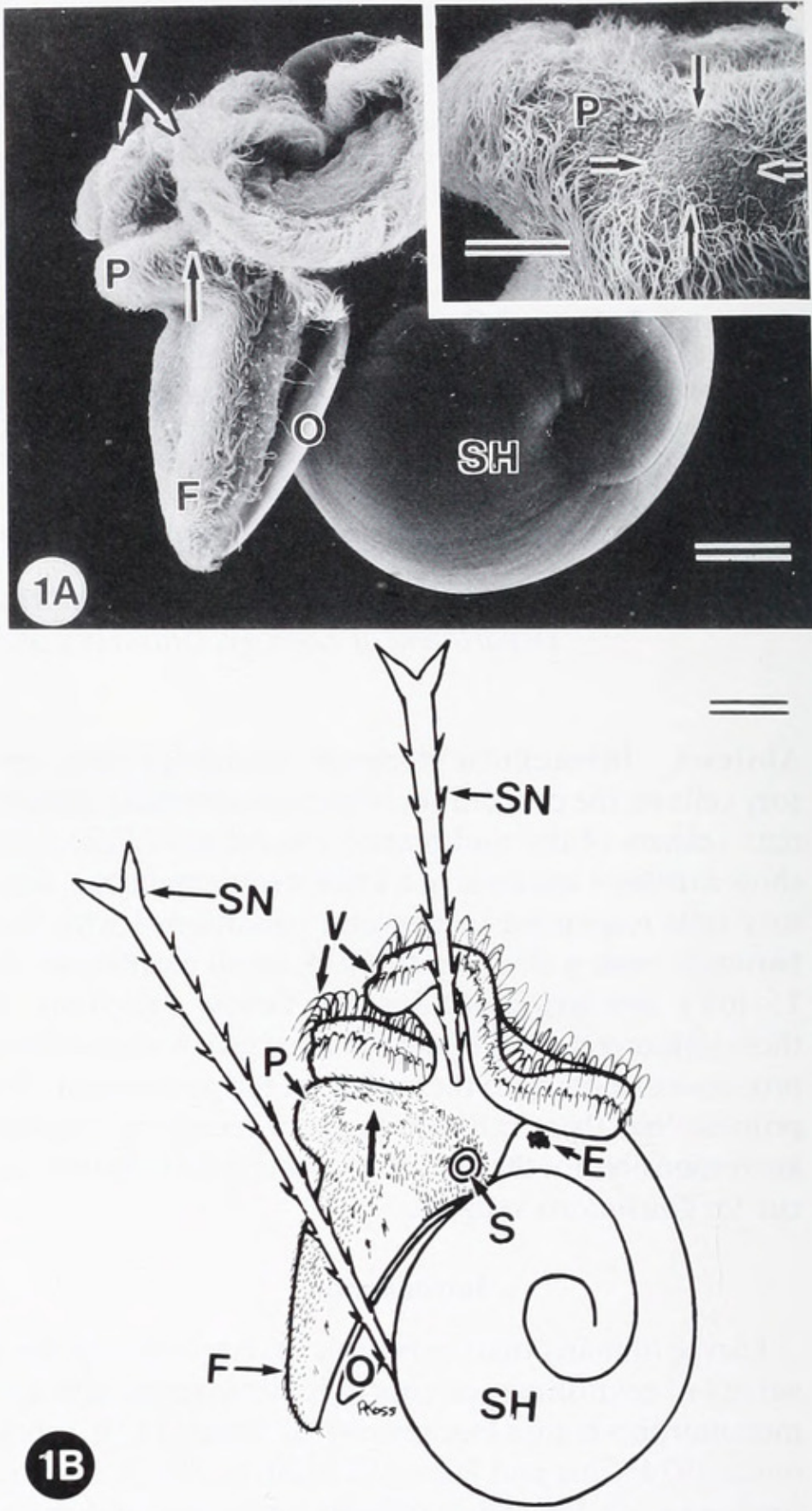

Figure 1. A. Scanning electron micrograph of competent veliger of Onchidoris indicating the location of one of the pair of settlement receptor fields (arrow). Bar $=50 \mu \mathrm{m}$. Inset shows a higher magnification of the receptor field (arrows) and propodium (P). Bar $=20 \mu \mathrm{m}$. B. Schematic drawing of the veliger preparation showing how veliger was pinned with cactus spines $(\mathrm{SN})$. Bar $=50 \mu \mathrm{m}$. Velum (V), propodium $(\mathrm{P})$, foot $(\mathrm{F})$, operculum $(\mathrm{O})$, shell $(\mathrm{SH})$, statocyst $(\mathrm{S})$, eye $(\mathrm{E})$

foot is still. The receptor fields on the sides of the propodium can be clearly seen in pinned veligers (Fig. 1A-B). Intracellular electrode recordings from the field show a mean resting potential of $-57.7 \mathrm{mV}(\mathrm{SE}=1.8, \mathrm{n}=24)$. No spontaneous receptor activity was observed while the preparation was in bath seawater, but an injury spike (15-20 mV amplitude, $300 \mathrm{~ms}$ positive phase duration) was occasionally seen upon penetration. Addition of 100 

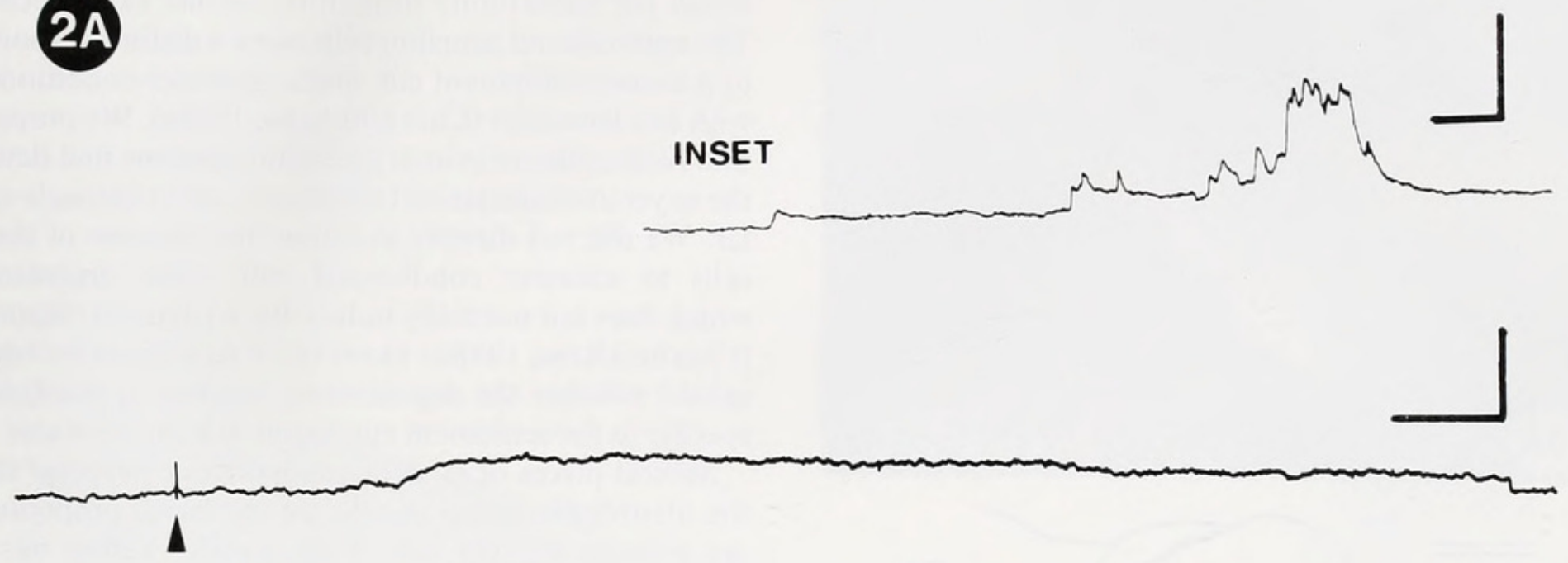

2B

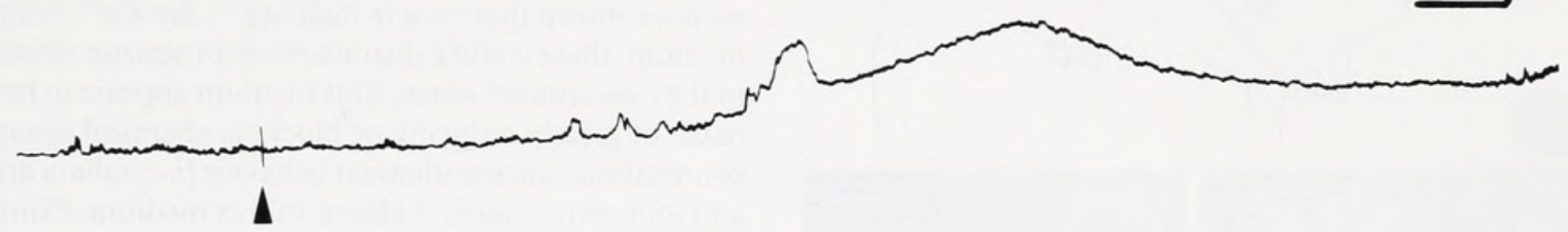

Figure 2. Intracellular electrode recordings from receptor cells in competent Onchidoris veligers. A. Receptor shows a response to the addition of $100 \mu \mathrm{l}$ of barnacle water (arrow) resulting in a slow depolarization that repolarizes to resting potential. Inset shows another example where high frequency receptor potentials are superimposed on slow depolarization. B. Another example of the receptor cell response to barnacle water (arrow). Horizontal scale $=3 \mathrm{~s}$ (A, B), $1 \mathrm{~s}$ (inset). Vertical scale $=15 \mathrm{mV}$ (A, B, inset).

$\mu \mathrm{l}$ of conditioned seawater results in a distinct, but somewhat variable change in the membrane potential.

The most common response to conditioned seawater is a slow depolarization, with a peak amplitude of about $5 \mathrm{mV}$ (range 3-15 mV) (Fig. 2A-B). The depolarization has a rapid onset and the membrane potential repolarizes back to the resting level within $30-60 \mathrm{~s}$. The initial depolarization usually occurs about $5 \mathrm{~s}$ after the start of the addition of the stimulus. The majority of this delay is likely due to diffusion time since the stimulus is applied several millimeters from the veliger. The depolarization is usually smooth, but occasionally small $(1-3 \mathrm{mV})$ high frequency, unitary depolarizations are superimposed on these slower depolarizations (Figs. 2A-B). Injection of up to $+5 \mathrm{nA}$ did not elicit action potentials. Addition of a subsequent stimulus aliquot usually produced a detectable response, however, the amplitude was reduced by about $40 \%$.

Control experiments in which we added culture seawater instead of stimulus produced no response. This ex- periment also served as a check for movement artifacts that could be misinterpreted as a slow change in membrane potential. Only 6 out of 24 veligers failed to show a detectable response where we were able to maintain stable resting potentials long enough to apply the stimulus. We could not detect a response either in the receptor cells or in whole animals when the veligers were bathed in $100 \% \mathrm{Co}^{++}$-seawater.

Lucifer Yellow injections of receptor cells reveal a single, flask-shaped cell located within the anterolateral ganglion (Fig. 3A-D). Distal dendritic processes extend toward the surface of the receptor field on the propodium (Fig. 3A-B). There was no indication of dye-coupling between receptor cells.

\section{Discussion}

We have characterized some of the electrophysiological properties of an identifiable group of cells in the anterolateral ganglia of competent veligers of the nudi- 

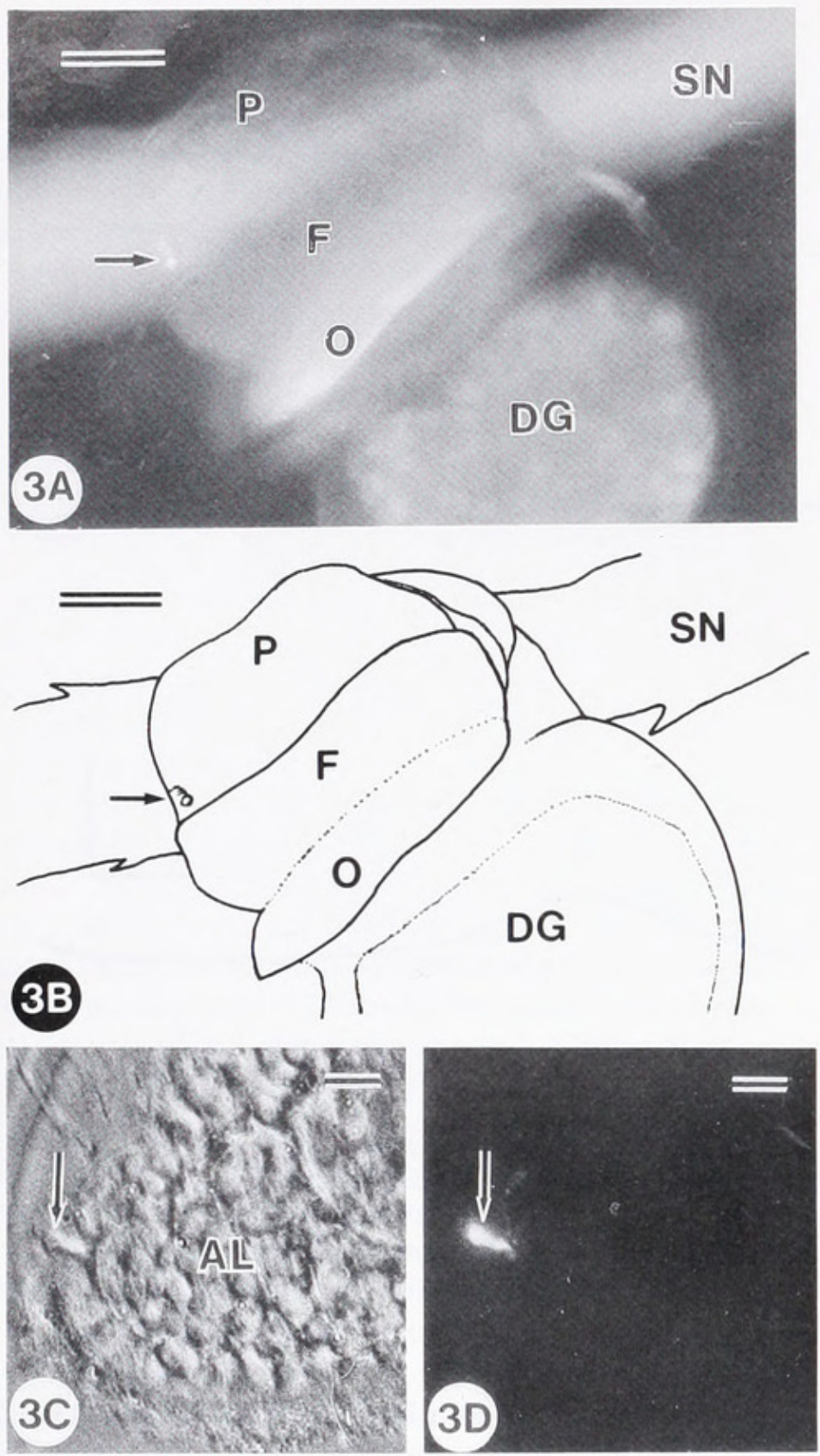

Figure 3. A. Fluorescence photomicrograph of a live veliger showing the location of Lucifer Yellow-filled receptor cell (arrow). Bar $=50$ $\mu \mathrm{m}$. Propodium (P), foot $(\mathrm{F})$, operculum $(\mathrm{O})$, digestive gland (DG), cactus spine (SN). B. Schematic view of A showing the orientation of the veliger and the location of the Lucifer Yellow-filled receptor cell (arrow). Bar $=50 \mu \mathrm{m}$. Propodium $(\mathrm{P})$, foot $(\mathrm{F})$, operculum $(\mathrm{O})$, digestive gland (DG), cactus spine ( $\mathrm{SN})$. C. Oblique thick $(2 \mu \mathrm{m})$ section through receptor field of Onchidoris veliger, viewed with phase contrast optics. showing a portion of a receptor cell filled with Lucifer Yellow (arrow) and the anterolateral ganglion ( $\mathrm{AL}$ ). $\mathrm{Bar}=3 \mu \mathrm{m}$. D. Fluorescence photomicrograph of the same section as $\mathrm{C}$ showing a portion of the Lucifer Yellow-filled receptor cell (arrow). Bar $=3 \mu \mathrm{m}$.

branch Onchidoris. These experiments became possible because the size and location of these ganglia made them accessible to intracellular recording techniques. While this nudibranch veliger species possesses other probable sensory organs (Bonar, 1978; Chia and Koss, 1982, 1984), their small size and obscured location do not afford the opportunity to perform similar experiments. The anterolateral ganglion cells show a distinct response to a known settlement cue that is seawater-conditioned with live barnacles (Chia and Koss, 1988a). We propose that these cells are primary receptor neurons that detect the as yet uncharacterized settlement cue in barnacle water. We did not directly examine the response of these cells to seawater conditioned with other organisms, which does not normally induce the settlement response (Chia and Koss, 1988a). However, it remains to be determined whether the depolarizing response is absolutely specific to the settlement cue found in barnacle water.

Several pieces of evidence support our proposal that the identifiable group of cells on the larval propodium are primary receptor cells. First, Lucifer Yellow fills of these receptor cells show that they are very similar to the "sensory receptor cells" in the unique anterolateral ganglia (Chia and Koss, 1988b). The receptor cells we have described and those described by Chia and Koss (1988b) have a dendritic tree that extends to the surface of the propodium and contributes to the receptor field. Second, we have shown that even in high $\mathrm{Mg}^{++}$, low $\mathrm{Ca}^{++}$bathing medium, there is still a distinct receptor neuron response to the conditioned water. This medium appears to be capable of greatly reducing or blocking chemical synaptic connections, since settlement behavior (i.e., ciliary arrest and foot contortions) is absent in this medium. Primary sensory cells should still respond.

We must comment on the effects of the high $\mathrm{Mg}^{++}$, low $\mathrm{Ca}^{++}$seawater bath on the receptor cell response. It was essential to use some anesthetic to immobilize the veligers for intracellular recordings from these small cells. The foot is active at this stage of development and settlement behavior involves strong foot contortions. However, despite the altered ionic concentration of the bath, we still see a distinct response in the receptor cells. There is some indication that the receptor potential is $\mathrm{Ca}^{++}$-dependent since we could not detect a receptor cell response when the veliger was bathed in $100 \% \mathrm{Co}^{++}$-seawater. We do not know if the absence of external $\mathrm{Ca}^{++}$ exerts its effect upon a second messenger (see below) or directly through $\mathrm{Ca}^{++}$channels. Regardless, it seems likely that the receptor cell response in the high $\mathrm{Mg}^{++}$, low $\mathrm{Ca}^{++}$seawater may be somewhat attenuated compared to the response that might occur in normal seawater.

Some of the variability in the amplitude and duration of the receptor cells' response may be due to the variable concentration of the uncharacterized ligand within the crude stimulus. The cellular response is short-lived, lasting only about $30 \mathrm{~s}$, yet the stereotypic settlement behavior (i.e., ciliary arrest and crawling) lasts for up to $30 \mathrm{~min}$ (Chia and Koss, 1988a). This suggests that a long duration complex motor pattern is triggered, even by brief 
exposure to the settlement cue. That subsequent additions of stimuli produced markedly reduced receptor cell responses suggests that there may be some "down regulation" of receptor sites on the cells. Further support for this idea is given by Chia and Koss (1988a) who found that veligers would not settle again within 24 hours after initial induction of settlement behavior at the onset of metamorphic competence. Another variable that we were unable to control is the level of metamorphic competency or the degree to which larvae are ready to perceive a settlement cue. There is likely some variability in competency between individual larvae within cohorts and this may explain the somewhat variable response. Furthermore, it seems likely that larvae that have delayed settlement and metamorphosis for a time after the onset of metamorphic competence may be more sensitive to settlement cues. Chia and Koss (1988a) note that larvae kept in culture greater than one week beyond onset of competence appear to settle more readily. These findings suggest that the timing of settlement and metamorphic competency and receptor sensitivity may be closely linked.

There is now some indication that settlement receptor cells in veligers may transduce sensory information in a manner similar to other olfactory neurons (Croll, 1983; Trotier and MacLeod, 1983; Getchell, 1977, 1986). In general, transduction of olfactory information involves binding of diffusable odorants to receptors on olfactory receptor cells, activation of guanine nucleotide-binding proteins (G-proteins) and adenylate cyclase, leading to the synthesis of the second messenger cyclic AMP (Pace et al., 1985; Sklar et al., 1986; Lancet et al., 1987). Nakamura and Gold (1987) demonstrated that conductance changes are gated by both cAMP and cGMP and suggested that these changes initiate the receptor cell depolarization. That larval settlement receptor cells may function similarly is indicated by the findings of Baxter and Morse (1987). They found that larvae of the abalone Haliotis may be induced to settle and metamorphose when bathed in isobutylmethyxanthine (iBuMeXan), which has been shown by Kopf et al. (1984) to elevate intracellular cyclic AMP levels in Haliotis sperm. We have demonstrated here that settlement receptor cells in Onchidoris depolarize in response to a known settlement cue. Future experiments using the Onchidoris preparation may involve manipulating second messenger levels while monitoring the response of these identifiable settlement receptor cells to a specific ligand. Results from these experiments may enable us to more fully understand the cellular processes of larval settlement cue recognition.

\section{Acknowledgments}

S. A. A. was supported by NSERC grant \#1427 to Dr. G. O. Mackie, F. S. C. was supported by NSERC grant
\#6083; and J. I. G. was supported by NSERC grant \#U0553 and Alberta Heritage Foundation for Medical Research.

\section{Literature Cited}

Arkett, S. A., G. O. Mackie, and C. L. Singla. 1987. Neuronal control of ciliary locomotion in a gastropod veliger (Calliostoma). Biol. Bull. 173: 513-526.

Baloun, A. J., and D. E. Morse. 1984. Ionic control of metamorphosis in larval Haliotis rufescens (Gastropoda). Biol. Bull. 167: 124138.

Baxter, G., and D. E. Morse. 1987. G protein and diacylglycerol regulate metamorphosis of planktonic molluscan larvae. Proc. Natl. Acad. Sci. USA 84: 1867-1870.

Bickell, L. R., F. S. Chia, and B. J. Crawford. 1981. Morphogenesis of the digestive system during metamorphosis of the nudibranch Doridella steinbergae (Gastropoda); conversion from phytoplanktivore to carnivore. Mar. Biol. 62: 1-16.

Bonar, D. B., and M. G. Hadfield. 1974. Metamorphosis of the marine gastropod Phestilla sibogae Bergh (Nudibranchia: Aoelidacea). I. Light and electron microscope analysis of larval and metamorphic stages. J. Exp. Mar. Biol. Ecol. 16: 227-255.

Bonar, D. B. 1978. Ultrastructure of a cephalic sensory organ in larvae of the gastropod Phestilla sibogae (Aoelidacea, Nudibranchia). Tissue Cell 10: 153-165.

Burke, R. B. 1983. The induction of metamorphosis of marine invertebrate larvae: stimulus and response. Can. J. Zool. 16: 1701-1719.

Chia, F. S., and R. Koss. 1978. Development and metamorphosis of the planktotrophic larvae of Rostanga pulchra (Mollusca: Nudibranchia). Mar. Biol. 46: 109-119

Chia, F. S., and R. Koss. 1982. Fine structure of the larval rhinophores of the nudibranch, Rostanga pulchra, with emphasis on the sensory receptor cells. Cell Tiss. Res. 225: 235-248.

Chia, F.S., and R. Koss. 1984. Fine structure of the cephalic sensory organ in the larva of the nudibranch Rostanga pulchra (Mollusca, Opisthobranchia, Nudibranchia). Zoomorphology 104: 131-139.

Chia, F. S., and R. Koss. 1988a. Induction of settlement and metamorphosis of the veliger larva of the nudibranch, Onchidoris bilamellata. Int. J. Invert. Reprod. 14: 53-70.

Chia, F. S., and R. Koss. 1988b. The fine structure of the newly discovered propodial ganglia of the veliger larva of the nudibranch, Onchidoris bilamellata. Cell Tiss. Res. (in press).

Chia, F. S., and M. E. Rice. 1978. Settlement and Metamorphosis of Marine Invertebrate Larvae. Elsevier/North Holland, New York. $290 \mathrm{pp}$.

Crisp, D. J. 1974. Factors influencing the settlement of marine invertebrate larvae. Pp. 177-277 in Chemoreception in Marine Organisms. P. T. Grant and A. M. Mackie, eds. Academic Press, London.

Croll, R. P. 1983. Gastropod chemoreception. Biol. Rev. 58: $293-$ 319

Getchell, T. V. 1977. Analysis of intracellular recordings from salamander olfactory receptor neurons. Brain Res. 123: 275-286.

Getchell, T. V. 1986. Functional properties of vertebrate olfactory receptor neurons. Physiol. Rev. 66: 772-818.

Kopf, S. G., C. A. Lewis, and V. D. Vacquier. 1984. Characterization of basal and methylxanthine-stimulated $\mathrm{Ca}^{2+}$ transport in abalone spermatozoa. J. Biol. Chem. 259: 5514-5520.

Lancet, D., Z. Chen, A. Ciobotariu, F. Eckstein, M. Khen, J. Heldman, D. Ophir, I. Shafir, and U. Pace. 1987. Toward a comprehensive molecular analysis of olfactory transduction. Pp. 27-32 in Annals of the New York Academy of Sciences, Vol. 510, Olfaction and Taste $I X$, S. D. Roper and J. Atema, eds. New York Academy of Sciences, New York 
McEuen, F. S. 1985. Reproductive patterns in holothuroids. Ph.D Thesis, The University of Alberta, Edmonton, Canada.

Nakamura, T., and G. H. Gold. 1987. A cyclic nucleotide-gated conductance in olfactory receptor cilia. Nature 325: 442-444.

Pace, U., E. Hanski, Y. Salomon, and D. Lancet. 1985. Odorant-sensitive adenylate cylase may mediate olfactory receptors. Nature 316 : 255-258.

Perron, F. E., and R. D. Turner. 1977. Development, metamorphosis, and natural history of the nudibranch Doridella obscura Verrill (Corambidae: Opisthobranchia). J. Exp. Mar. Biol. Ecol. 27: 171185

Scheltema, R.S. 1974. Biological interactions determining larval settlement of marine invertebrates. Thalassia Jugosl. 10: 263-296.

Sklar, P. B., R. H. Anholt, and S. H. Snyder. 1986. The ordeorant- sensitive adenylate cyclase of olfactory receptor cells. J. Biol. Chem. 261: $15538-15543$.

Thompson, T. E. 1958. The natural history, embryology, larval biology, and post-larval development of Adalaria proxima Alder and Hancock (Gastropoda, Opisthobranchia). Phil. Trans. R. Soc. Lond. 242B: 1-57.

Thompson, T. E. 1962. Studies on the ontogeny of Tritonia hombergi Cuvier (Gastropoda, Opisthobranchia). Phil. Trans. R. Soc. Lond. 245B: $171-281$.

Todd, C. D. 1979. The population ecology of Onchidoris bilamellata (L.). J. Exp. Mar. Biol. Ecol. 41: 213-255.

Trotier, D., and P. MacLeod. 1983. Intracellular recordings from salamander olfactory receptor cells. Brain Res. 266: 225-237.

Yool, A. J., S. M. Grau, M. G. Hadfield, R. A. Jensen, D. A. Markell, and D. E. Morse. 1986. Excess potassium induces larval metamorphosis in four marine invertebrate species. Biol. Bull. 170: 255266. 


\section{$2 \mathrm{BHL}$ Biodiversity Heritage Library}

Arkett, Stuart A et al. 1989. "Identified Settlement Receptor Cells in a Nudibranch Veliger Respond to Specific Cue." The Biological bulletin 176, 155-160. https://doi.org/10.2307/1541583.

View This Item Online: $\underline{\text { https://www.biodiversitylibrary.org/item/17430 }}$

DOI: https://doi.org/10.2307/1541583

Permalink: https://www.biodiversitylibrary.org/partpdf/10952

\section{Holding Institution}

MBLWHOI Library

\section{Sponsored by}

MBLWHOI Library

\section{Copyright \& Reuse}

Copyright Status: In copyright. Digitized with the permission of the rights holder.

License: http://creativecommons.org/licenses/by-nc-sa/3.0/

Rights: https://biodiversitylibrary.org/permissions

This document was created from content at the Biodiversity Heritage Library, the world's largest open access digital library for biodiversity literature and archives. Visit BHL at https://www.biodiversitylibrary.org. 